\title{
Eq
}

\section{A L'ENSENYAMENT CAL COMBATRE LA PASSIVITAT}

Aquests darrers temps molta gent parla de política sense por de discrepar obertament de l'interlocutor. Això segurament vol dir, entre altres valoracions, que som una mica més lliures. De fet han canviat coses tant a Catalunya com a Espanya. La política, aquesta ciència social bescantada per la falsetat de persones que en viuen a esquena dels altres i que no aterren a la realitat, ha revaloritzat un paper que no havia d'haver perdut mai: explicar qualsevol qüestió amb tots els ets $i$ uts per tenir millor potestat de decidir. Ara, en aquest cicle que acaba de començar, cal demostrar-ho amb fets i no només amb paraules.

La política del fet consumat no ha agradat mai a l'escola, vingués d'on vingués. L'escola, i els actius professionals que hi treballen, en els darrers temps han comptat per poca cosa pels governs que s'han tingut. Lleis $\mathrm{i}$ normatives sorgides de la fosca gola de la penombra, ens eren presentades a qualsevol nivell educatiu com la solució que arreglaria un ensenyament que s'ha aguantat per la voluntat, el voler i saber fer dels que hi treballen, més que per lleis que engendraven confrontació i crispació. ¿Què en farem, ara, de la controvertida llei de qualitat ¿Què en farem, ara, d'un ensenyament de la religió catòlica, posat en calçador a un Estat que es declara laic? ¿Què en farem, ara, de la desigualtat social a les aules, tolerada a determinades escoles d'èlit -i no tant-com si no passés res de res? ¿Què en farem, ara, dels concerts educatius que graviten descontrolats? ¿Què en farem, ara, dels alumnes que s'esmunyen llastimosament de l'escola amb una perspectiva personal i professional negra que els marcarà de per vida?

Les preguntes que aportem, ho sabem prou bé, generen debat en converses d'ensenyants segons el nivell educatiu en què estem immersos, tot $i$ que les orelles dels que fins ara havien d'escoltar eren poc receptives. I així ens ha anat. I avancem que no som nosaltres sols, els ensenyants, qui les hem de resoldre, tot i que si se'ns deix parlar i se'ns vol escoltar hi tenim a dir. Per això és necessari que la veu del professorat agafi potència de grup i que les resolucions que adoptin els governants siguin d'equip, i no únicament de partit. Entenem que mai un partit -0 un bipartit o fins un tripartit- per si sol pot fer gravitar sobre seu una decisió general que és de nació. La política educativa ha de ser de tots i no d'uns quants, per molts que siguin, si no està abocada irremeiablement al fracàs.

Situar l'ensenyament de Catalunya en el punt més alt del rànquing és el que demanda un pervindre educativosocial de futur, que per ser potent ha de poder comptar amb efectius preparats. Catalunya no pot deixar passar el tren d'una educació que volem que sigui punta de llança. Ens agradaria en aquesta nova etapa política que tot just comença, que es busqués l'interès general per resoldre els problemes per sobre dels particularismes nefastos que ens han encaixonat, en ares d'aconseguir un ensenyament de qualitat per a tothom, sense exclusions. Per arribar a aquesta meta, segurament faran falta accions de convicció per redreçar certes actituds i comportaments, que ben explicades han de permetre que l'ensenyament no es vegi abocat a canvis i més canvis per processos electorals i per polítiques partidistes.

La passivitat estronca la lliure circulació de les idees. Si no volem quedar eixorcs de pensament cal combatre la indiferència. L'aposta és apassionant. T'hi apuntes? 